\title{
BȦSIC QUALITATIVE PARAMETERS OF COW COLOSTRUM AND THEIR DEPENDENCE ON SEASON ÃND POST PARTUM TIME
}

\author{
J. KLIMEŠ, P. JAGOŠ, J. BOUDA and S. GAJDU゚క̌KK \\ Department of Diagnosis, Therapy and Control of Animal Diseases, \\ University of Veterinary Science, 61242 Brno
}

Received November 8, 1984

\begin{abstract}
Klimeš J., P. Jagoš, J. Bouda, S. Gajdůšek: Basic Qualitative Parameters of Cow Colostrum and their Dependence on Season and Post Partum Time. Acta vet. Brno, 55, 1986: 23-39.

Under conditions of large scale dairy unit for 2144 cows 19 physicochemical and biochemical parameters of cow colostrum and the influence of season and time after parturition on these parameters have been studied. Average samples of colostrum from the first milking, on the 3rd and 5th day post parturition were collected from cows - cross-breds of Bohemian Pied x Black Pied Lowland breeds. In summer (June) and winter (February) season colostrum of 13 and 24 cows, resp. was examined.

In most parameters the highest values were found in colostrum from the first milking, the most pronounced decrease being observed for the first three days after parturition. Only the $\mathrm{pH}$ and lactose values were found to be lowest in colostrum from the first milking. The fat content, rennet coagulation time of colostrum and potassium concentration varied without a marked dependence upon the time elapsed after parturition. In summer season, significantly higher values of vitamin A, buffer capacity and dry matter were observed in at least two out of three investigated milkings; in winter, significantly higher phosphorus levels were found.

Approximately 1000 times higher GMT activity when compared with that in cow blood plasma was demonstrated in colostral whey.

Higher titratable acidity, higher levels of protein, gamma globulins, sodium, GMT activity and lower lactose concentration were determined in colostrum samples from the first milking with a concentration of total protein in whey over $120 \mathrm{~g} / \mathrm{l}$, when compared with colostrum with a decreased total protein content in whey.

The determination of total protein concentration in colostral whey from the first milking could be regarded as a decisive criterion of the evaluation of colostrum quality. On the basis of colostrum quality the level of nutrition, maintenance, and health condition of mother in the last gravidity trimester may be assessed together with other factors which will influence further development of the calves.
\end{abstract}

Cow, calf, colostrum, protein, total protein, gamma globulins, GMT, fat, lactose, vitamin $A$ and $E$, titratable acidity, $p H$, buffer capacity, coagulability, dry matter, ash, macroelements.

The significance of colostrum for a newborn calf is due mainly to a high content of maternal antibodies and a high nutritional value. The latter is defined by the content of easily digestible proteins, fats, minerals and vitamins. Colostrum contains also a great amount of enzymes, non-specific antibacterial factors and cell elements which can take part in the defence of an organism against infection (Reiter 1978; Norcross 1982). 
The amount of proteins in colostrum is about five times higher than that in milk, particularly due to a high content of immunoglobulins. Casein concentration is approximately 1.5 times higher (Mitju shin 1979) and differs from casein of normal milk by the distribution of individual fractions (Gajdůšek 1969).

The concentration of total protein in colostral whey from the first milking is $1.5-2$ times higher than that in maternal blood serum (Bouda 1979) and its level increases till the 4th lactation (Lambrecht et al. 1982). The total protein content in colostral whey decreases in metabolic acidosis, hypogammaglobulinaemia and liver diseases in dairy cows ( $\mathrm{Ja}$ goš et al. 1980).

Immunological value of colostrum follows first of all from the immunoglobulin or gamma globulin content. Their concentration is influenced by the age of dairy cows, breed (Kruse 1970), milking out and suckling colostrum prior to parturition (Logan 1978). The Ig level differs between animals (Messerli and Fey 1973) and is not influenced by the amount of colostrum produced (Logan 1977).

High activity of gammaglutamyltransferase (GMT) in calf blood in the period of colostral nutrition (Bouda et al. 1980) suggests that colostrum is an important source of this enzyme (Thompson and Pauli 1981). According to the GMT activity in calf blood the feeding of calves by colostrum could be assessed.

Both higher (Mitjušin 1979) and lower fat content in colostrum than in milk (Gajdůšek 1969) are reported in literature. The level of fat undergoes a great individual variation, the differences being observed also among individual quarter samples (S t ojičevič 1977).

The lactose content in colostrum increases from the initially low level (Mitjušin 1979).

Colostrum is virtually the only natural source of vitamin A for a newborn calf (Moore 1957). It contains roughly 5 times more vitamin A than milk ( $\mathrm{Zucker}$ et al. 1980).

The level of vitamin $\mathrm{E}$ in colostrum was found to be approximately 2.5 times higher than the values obtained in blood plasma of dairy cows (Bouda et al. 1980). In cows with puerperal complications the decrease of vitamin $E$ level in colostrum was observed by Nezhdanov and Kuzněcov (1978).

Colostrum is characterized by a lower pH value than milk. Slightly acid reaction of colostrum and milk is caused by the presence of proteins, dihydrogen phosphates, citrates and carbon dioxide (Še bela and Klíčník 1977).

Titratable acidity of colostrum is roughly $2-2.5$ times higher than that of milk. The longer the duration of dry period of a dairy cow, the higher is the titratable acidity. On farms with low incidence of scours in calves higher values of titratable acidity of colostrum were usually found when compared with those places where a high incidence of this disease (Mitjušin 1979) was occurring.

On the other hand, Kavak (1984) observed a higher number of still-born or dying calves and impaired reproduction parameters in cows producing colostrum with a higher titratable acidity. Acidosis in dairy cows was, however, the cause of high colostrum acidity whereas in the first case the titratable acidity was found to increase owing to the high concentration of proteins in colostrum.

Buffer capacity of colostrum depends first of all upon the content of proteins, phosphates and citrates. It influences the secretion of digestive juice and an overall water and electrolyte balance of calf organism (Jančařík 1977). It also defines, to a certain measure, pH of gastric and duodenal content and all the more the efficiency of digestive processes and possibly of microbial content.

The rennet coagulation time of milk is given first of all by the presence of protein fractions and by mutual ratio of individual forms of calcium and phosphorus (Batra and De Man 1964; Še bela and Gajdůšek 1969).

Disturbances of rennet coagulation of milk could be the cause of scours in calves (Johnston and Mac Lachlan 1977; Johnston et al. 1980). Mitjušin (1979) refers that on farms with a good health condition of newborn calves a shorter time of rennet coagulation of milk was observed than in the case of problem farms.

Colostral dry matter is approximately two times higher than that of milk, this being due to the content of proteins, fats and minerals. Similarly, the ash content in colostrum is higher than in normal milk. The content of $\mathrm{Ca}$ and $\mathrm{P}$ and of $\mathrm{Mg}$ in colostrum is about two and three times, resp. higher than their concentration in milk (Gueguen 1961).

The calcium content in colostrum gradually decreases post parturition. Calcium is essential for the rennet coagulation of colostrum and milk in calf abomasum. The phosphorus content was found to be the highest in colostrum from the 1st milking as well. Magnesium salts facilitate the meconium expulsion due to their laxative effect. Ste in bach and Meyer (1965) and Meyer and Steinbach (1970) have observed a positive effect of magnesium taken up with colostrum upon the calf resistance to diarrheal diseases. The authors explain this effect mostly by stimulating effect on phagocytosis and by the formation of large, hemoglobin-rich erythrocytes. These 
authors have also observed the dependence of the $\mathrm{Mg}$ content in colostrum on the breed. The sodium concentration gradually decreases with the time after parturition. Its content influences the colostrum coagulability, influencing thus the digestion in calf abomasum(Mitjushin 1979). Steinbach and Meyer (1965) have found higher sodium concentrations in colostrum of primiparae. The potassium content in colostrum from the 1 st milking is not, contrary to other macroelements, higher than in subsequent milkings (Senft and $\mathrm{R}$ appen 1964; Stein bach and Meyer 1965; Kratochvíl and Zíková 1981). The later the colostrum samples from the 1st milking are obtained, the lower are the values of $\mathrm{Ca}, \mathrm{Mg}$ and $\mathrm{Na}$, the $\mathrm{K}$ concentration being, however, higher. The $\mathrm{Ca}, \mathrm{Mg}$ and $\mathrm{Na}$ concentrations decrease with the increasing volume of milking (Steinbach and Meyer 1965). Nezhdanov and Kuzněcov (1978) have observed the rise of colostral $\mathrm{Ca}, \mathrm{Na}$ and $\mathrm{K}$ concentrations in puerperal complications.

Colostrum represents one of the most significant factors in the mother-offspring relation, which has been studied in our laboratory. Although many findings have been published in literature concerning the colostrum composition, the results were usually obtained from relatively small sets of animals under small-scale breeding conditions, over short-time period or using less acurate methods than the latest diagnostic laboratory methods. The colostrum quality is closely connected with the health condition of dairy cows and their calves. That is the reason why our work has been concerned with the study of colostrum composition and dynamics of its time-dependent changes after parturition, season and health condition of cows under conditions of large-scale technology.

\section{Materials and Methods}

Within two hours after parturition average samples of colostrum from the first milking were collected from cows at large scale cow-house for 2144 animals. Further samples were taken on the 3rd and 5th day after parturition. The cows were in their 2 nd -4 th lactation, cross-breds of Bohemian Pied and Black Pied Lowland breeds. In summer season (June) colostrum of 13 cows was examined, in winter season (February) colostrum of 24 cows was investigated. Clinical and biochemical examination of dairy cows was carried out 3-4 weeks prior to and 3-4 weeks after the parturition. Nutrition, zoohygiene, and health condition of calves, including repeated biochemical and hematological examinations, were followed at the same time.

The contents of proteins, fat, lactose, vitamin A and E, the levels of titratable acidity, pH and buffer capacity, rennet coagulation time, the contents of dry matter and ash and the concentration of $\mathrm{Ca}, \mathrm{P}, \mathrm{Mg}, \mathrm{Na}$ and $\mathrm{K}$ were determined in colostrum samples. The levels of total protein, gamma globulins and the GMT activity in colostral whey were found. The values of $\mathrm{pH}$, titratable acidity, buffer capacity and coagulability were determined immediately after sampling. In order to determine the contents of fat, protein and lactose the samples were conserved by potassium dichromate and stored in a refrigerator at $+4{ }^{\circ} \mathrm{C}$ but no longer than for three days. Samples for other analyses were maintained frozen at $-16^{\circ} \mathrm{C}$.

Colostral whey was obtained by the addition of $0.2 \mathrm{ml}$ of rennet (Lactochym K) and $0.1 \mathrm{ml}$ of $10 \% \mathrm{CaCl}_{2}$ to $20 \mathrm{ml}$ of colostrum. After stirring and 60 minutes lasting incubation at $37{ }^{\circ} \mathrm{C}$ the whey was separated by centrifugation. Total protein was then determined photometrically on the basis of biuret reaction using Bio-test (Lachema Brno). Electrophoretic protein separation was carried out on cellulose acetate strips on the Microphor Boskamp instrument and individual fractions were then evaluated densitometrically. The GMT activity was defined photometrically using the Bio-test (Lachema Brno) after the dilution of colostral serum. The contents of fat, protein and lactose were determined by infrared analysis on a Multispec instrument. The levels of vitamin A and $E$ were defined spectrofluorometrically (Bou da et al. 1980). The determination of titratable acidity was carried out according to the Czechoslovak standard CSN 570530, twofold concentration of $\mathrm{CoSO}_{4}$ in the reference solution being however used. The actual value of colostral $\mathrm{pH}$ was determined at laboratory temperature using the $\mathrm{pH}$-meter. The buffer capacity of colostrum was calculated on the basis of the $\mathrm{pH}$ change within 15 minutes after the addition of $0.1 \mathrm{~mol} .1^{-1} \mathrm{HCl}$ in the amount of $1 \mathrm{ml} / 10 \mathrm{ml}$ of colostrum $(\mathrm{Holm}$ and We b b 1930; La ne et al. 1970). The rennet coagulation time was determined at $37^{\circ} \mathrm{C}$ in a usual way (Teplý et al. 1976).

Colostral dry matter was determined according to the Czechoslovak standard CSN 570530. Ash content was defined after burning in a muffle furnace at $50 \overline{0}-550^{\circ} \mathrm{C}$ for $48-72$ hours, the initial sample weight being approximately $5 \mathrm{~g}$. The samples were pre-dried according to the above mentioned methods of the dry matter determination.

There were sometimes non-burnt residues in colostrum from the 1st milking which were removed at the temperature of a gas burner after the addition of several drops of $30 \%$ solution of $\mathrm{H}_{2} \mathrm{O}_{2}$. Macroelements were determined upon the dry mineralization of samples using the atomic absorption spectrophotometry, the only exception being made at the determination of 

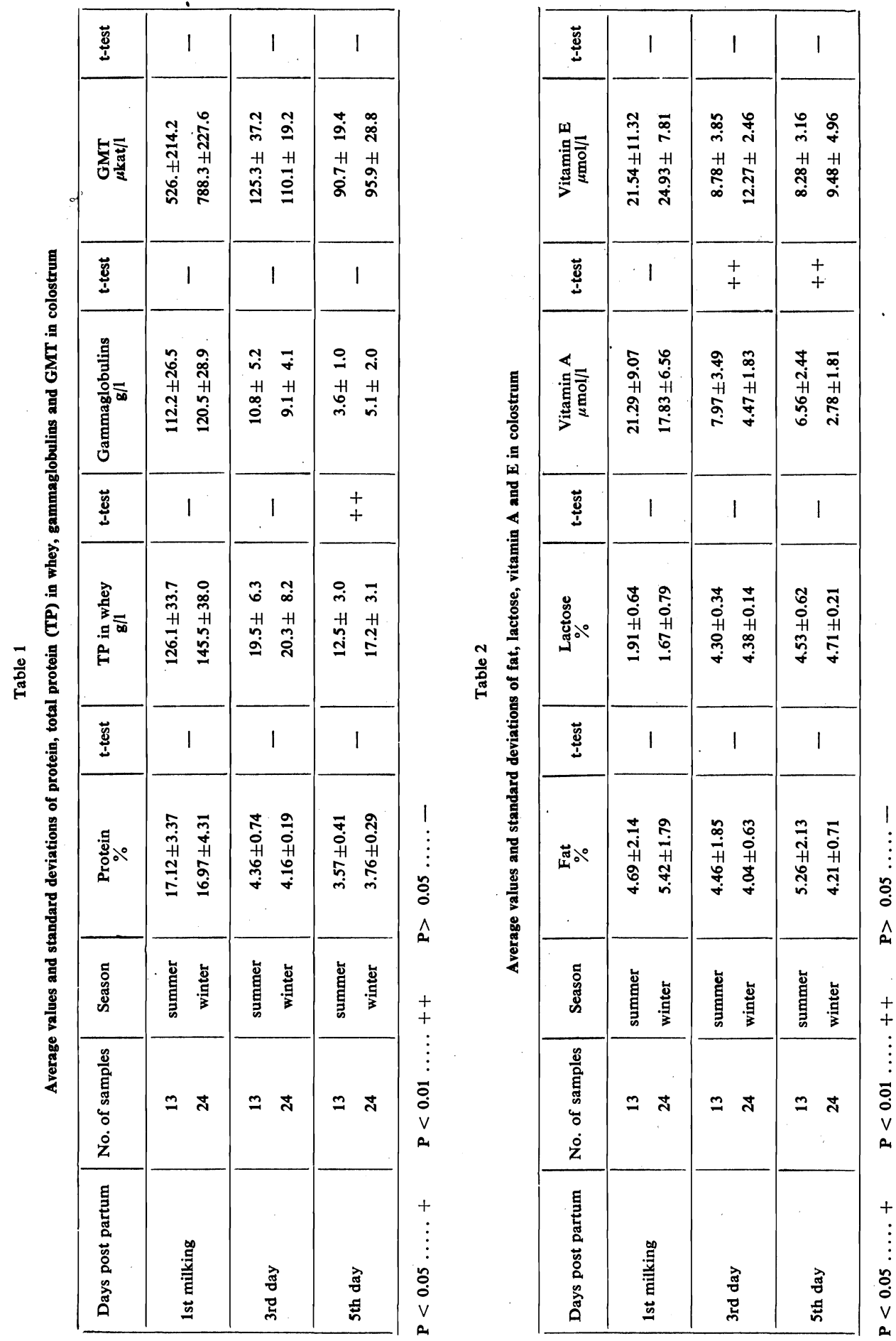
phosphorus. The mineralized sample was obtained by dissolving the ash in $5 \mathrm{ml}$ of $\mathrm{HCl}$, the concentration being $3 \mathrm{~mol} .1^{-1}$, and making up to $25 \mathrm{ml}$ with distilled water. The solution obtained in this way was further diluted 50 times with redistilled water and 50 times with $1 \%$ solution of $\mathrm{La}\left(\mathrm{NO}_{3}\right)_{3}$ in $0.1 \mathrm{~mol}^{-1} \mathrm{1}^{-1} \mathrm{HCl}$ for the determination of $\mathrm{Mg}, \mathrm{Na}, \mathrm{K}$ and $\mathrm{Ca}$, resp. Phosphorus was determined photometrically using the Bio-test (Lachema Brno) from the undiluted sample.

Statistical evaluation of the results was carried out on a Hewlett-Packard 9810 A calculator. -The Student t-test was used to determine the difference significance between two selected sets. To assess the differences among individual samplings the method of simple variance analysis and Duncan test were applied.

\section{Results}

Clinical and clinico-biochemical examinations have revealed subclinical methemoglobinaemia $(5.1-6.6 \%$ of methemoglobin out of the total $\mathrm{Hb})$, caused by the higher content of nitrates in fed rye, in a selected set of dairy cows in summer season. Mildly elevated GMT activities in blood plasma have been observed in several of the followed dairy cows in both summer and winter season in the periparturient period.

The average values and standard deviations of the followed parameters, as well as statistical evaluation of differences between summer and winter season are presented in Tables $1-5$. In summer season, significantly higher values of buffer capacity (in all three examined milkings), vitamin A and dry matter (3rd and 5th day after parturition) were determined. In winter season, significantly higher levels of total protein in colostral serum (5th day post partum), sodium (5th day post partum), potassium (3rd day post partum) and phosphorus (3rd and 5th day post partum) were found.

Statistical evaluation of differences among followed parameters in the 1st milking, 3rd and 5th day post partum are shown in Table 6 and 7. In most parameters the statistically significant differences were observed between the values from the 1st milking and 3rd day post partum and between those from the first milking and 5th day post partum. It follows from the presented that the greatest changes in the colostrum composition occur up to the third day after parturition. The kinetics of fat content, time of rennet coagulation and potassium concentration were found to be irregular. In Table 8 the comparison of colostral parameters from the 1st milking of two sets of animals with deficient and satisfactory total protein level in whey is presented. In the set with a satisfactory total protein concentration in whey (over $120 \mathrm{~g} / \mathrm{l})$ statistically significantly higher values were found of the following parameters: colostral protein, gamma globulins, GMT activity, titratable acidity and sodium. The lactose content was found to be significantly lower. The colostrum from the 1st milking is characterized by a high individual variability of parameters. It is valid particularly in the case of vitamin $A$ and $E$ and fat contents and for the GMT activity.

\section{Discussion}

Concentrations of protein in colostrum from the 1st milking found by us are in accordance with findings of Gushul et al. (1975) and Kvapilík et al. (1975). Senft and Rappen (1964) have observed a lower content since the sample taking was carried out as late as 10.5 hours after parturition. We have observed the most significant reduction in protein content within three days post partum. Kvapilík et al. (1975) have noted that the stabilization of the protein content is the slowest of all milk components, i.e. about 8th day after parturition. The total whey protein level was higher in winter than that in summer season, the inverse relation being observed 

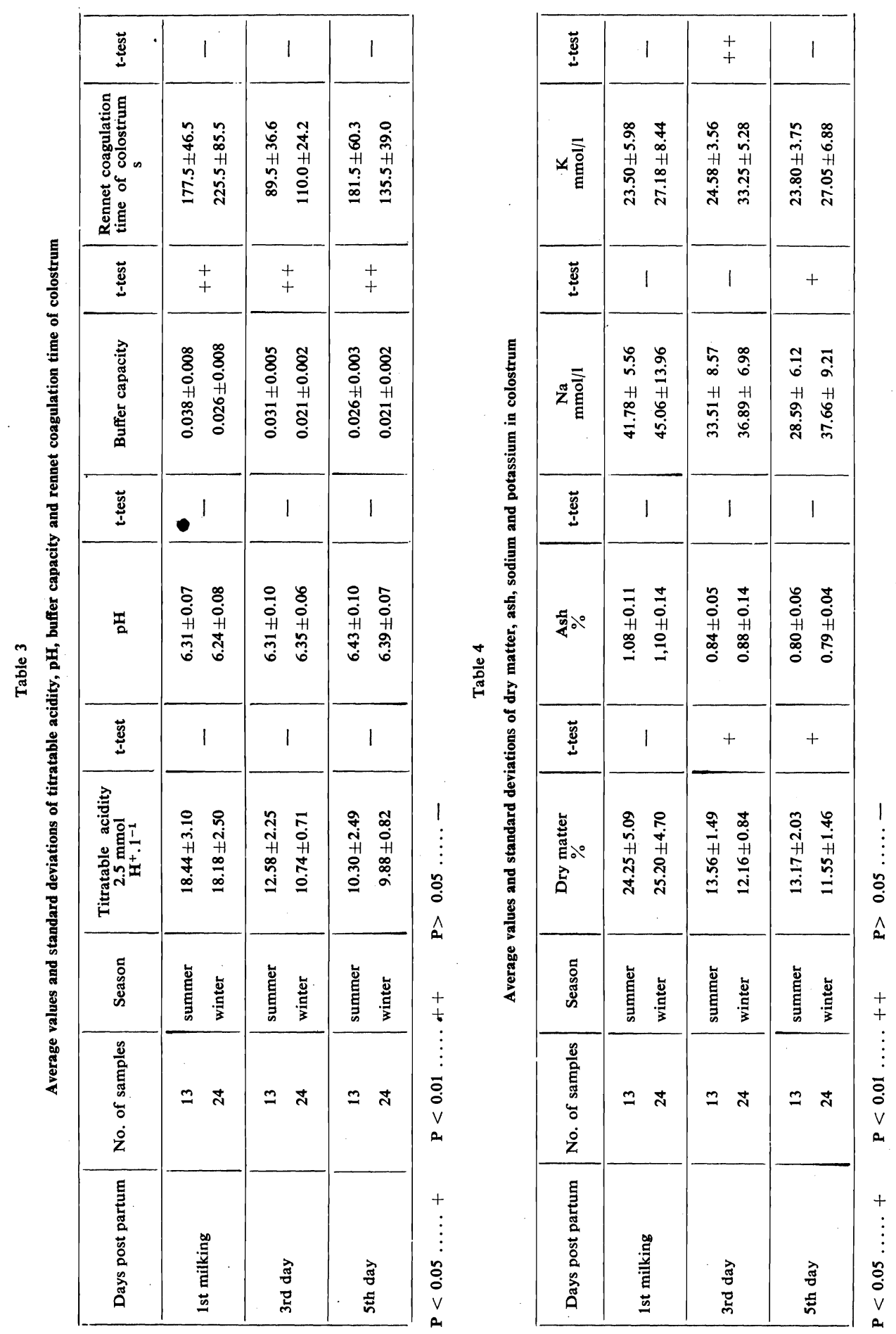
in colostral proteins. The increase of total protein in colostrum in summer season appeared to be caused by the higher casein content. In colostral serum levels of total protein similar to those found by Gushul et al. (1975) were observed. Kvapilík et al. (1975) have reported that the total protein content in whey reaches the level of normal milk on the 3rd day after parturition which is in agreement with our findings. In winter season higher concentrations of total protein in colostral whey have been observed, these results being in accordance with our previous findings (Jagoš et al. 1983; Bouda et al. in press). Schmidt et al. (1982) have reported identical data for immunoglobulins that are in positive correlation with total protein. The gamma globulin concentrations in colostral whey found by us correspond to the findings presented by Dardillat et al. (1978). These authors assume the optimal concentration of gamma globulins to be $120 \mathrm{~g} / \mathrm{l}$, that below $100 \mathrm{~g} / \mathrm{l}$ is regarded as unsatisfactory.

The GMT activity in colostral whey was found to be approximately 1000 times higher when compared with blood plasma of dairy cows, which is indicative of a more intensive transfer of this enzyme into the mammary gland secretion. The actual representation of GMT in colostrum is even higher since only $63 \%$ of GMT of total colostrum is contained in whey (Yasumoto et al. 1976). These authors have also proved that GMT is present in a bound form in membrane structures (milk microsomes) of skim milk and is not bound to immunoglobulins. Thompson and Pauli (1981) reported that the GMT activities in colostrum were 800 times higher than those in cow blood serum.

As for the fat content, neither statistically significant differences among individual milkings nor dependence on season have been proved. This is in agreement with literature data showing that fat is a very variable component of colostrum, dependent to a great extent upon the actual body condition and nutrition of the dairy cow (Senft and Rappen 1964; Kvapilík et al. 1975).

In colostrum from the 1st milking a slightly lower lactose value, compared to that found by Senft and Rappen (1964) and Mitjušin (1975) has been determined.

The levels of vitamin A in colostrum found by us are in agreement with the data published by Steinbach and Meyer (1976), Stein bach et al. (1970), Bouda et al. (1980), Erickson et al. (1981). Seasonal differences were found to be statistically significant, similarly as in the case of several other parameters, on the 3rd and 5th day only. This is accounted for by great individual differences, and thus by high variance or high coefficient of variation of the colostrum from the 1st milking. These differences gradually decrease with the time after parturition.

The observed level of vitamin $\mathrm{E}$ is similar to the values presented by Bouda et al. (1980) and Erickson et al. (1981).

The values of titratable acidity were found to be in the range reported also by Senft and Rappen (1964), Alikajev and Podkopajev (1966), Alikajev and Tumanov (1977) and Mitjushin (1979) while Kvapilík et al. (1975) found somewhat lower and Gushul et al. (1975) somewehat higher values of titratable acidity. In summer season the observed data were higher than those in winter, which was probably due to the increased protein content; this difference was not, however, statistically significant. Kadlec (1982) reported similar seasonal differences in milk.

Colostral $\mathrm{pH}$ was found to increase with the time past parturition, similarly as published by Senft and Rappen (1964).

Markedly higher buffer capacity of colostrum was observed in summer season when compared with winter. This may be due to a slightly higher protein content in colostrum during this part of year. The buffer capacity had a decreasing tendency with advancing lactation which could be explained by the reduction in protein 

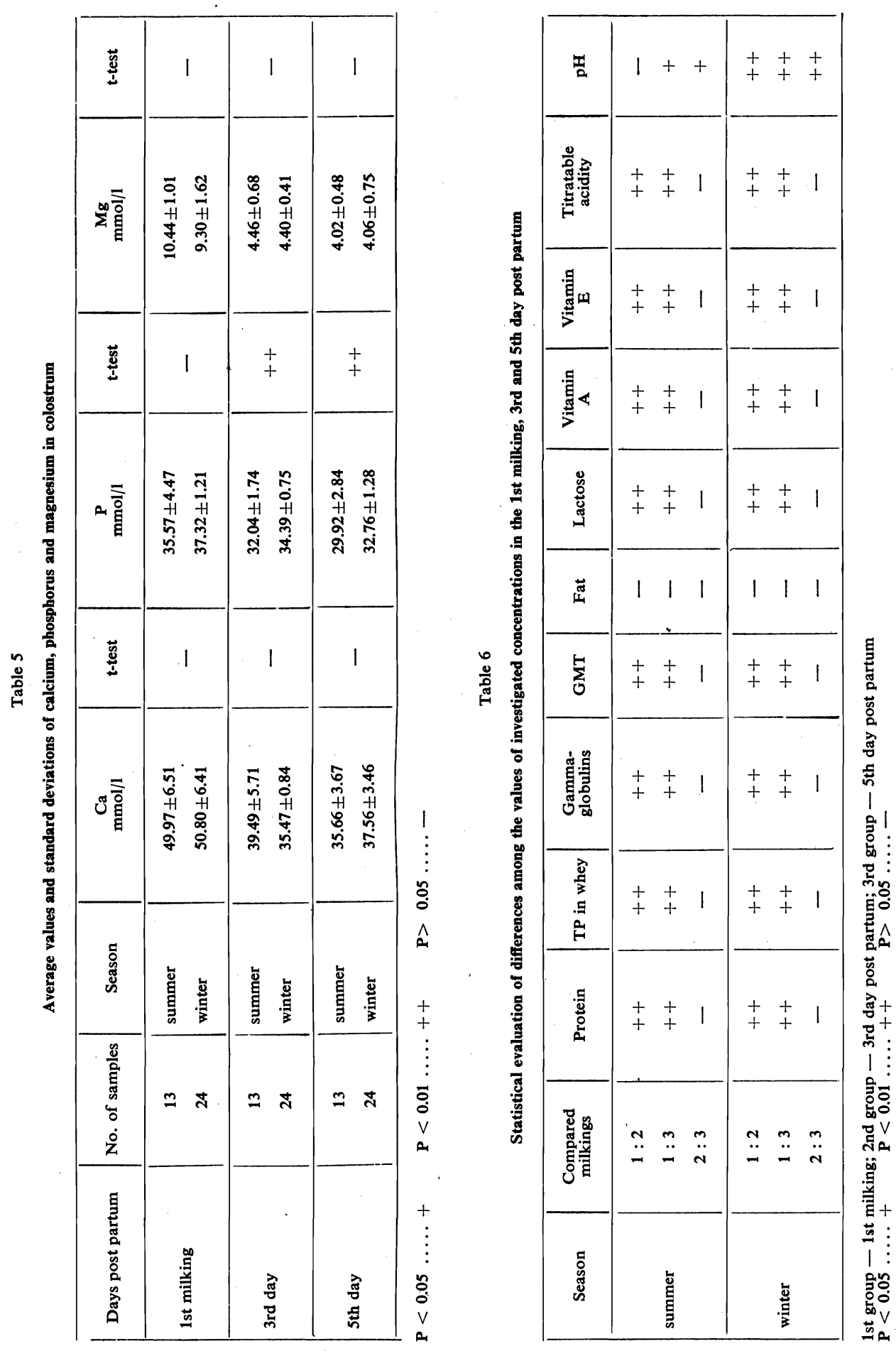
content (Lebeda et al. 1970) and in minerals in colostrum. The time of milk or colostrum coagulation is dependent upon the rennet used, this being the reason why only relative and not absolute comparison with results of other authors is possible. Sebela and Klíčník (1975) reported a shorter rennet coagulation time for colostrum than that found in dairy cows in full lactation. The shortest coagulation time has been measured on the 3rd day after parturition, which was also confirmed by us. Also Kvapilík et al. (1975) observed that from the 2nd to 7th day post partum the coagulation of colostrum was more rapid than in subsequent days. The coagulation of colostrum from the 1st milking differed also in quality. Visually a gradual congealation could be noted, whereas in milk a rapid formation of flaked precipitate was observed. Also the amount of whey obtained from the 1st milking was smaller, this being in relation with the higher dry matter content and a different structure of the formed curd due to the changed ratio of proteins and minerals.

The values of dry matter and ash in colostrum published in literature corroborate the values found by us (Senft and Rappen 1964; Gajdůšek 1965; Kopecký 1967; Kratochvíl and Zadražil 1981; Kratochvíl and Zíková 1981). Kvapilík et al. (1975) assume that the dry matter value decreases to the level of milk already on the 3rd lactation day which is evident also from our investigation. Kratochvíl and Zadražil (1981) found the dry matter content to reach $12.59 \%$ already on the 2nd day after parturition.

Many literature data have been published on the content of macroelements in cow's colostrum (Kirchgessner 1959; Gueguen 1961; Senft and Rappen 1964; Steinbach and Meyer 1965; Zinovjeva 1968; Hajdu 1977; Linden and Maraval 1979; Roux et al. 1979; Kratochvíl and Zíková 1981; Seidel et al. 1982). It follows from these reports that the concentration of macroelements varies within a rather broad range given by individual differences and irregular fluctuations in dependence upon the time elapsed after parturition.

The highest concentration of most macroelements was found in colostrum from the 1st milking which is in agreement with data published in literature. Only the potassium content was changing irregularly. Garret and Overmann (1940), Comberg and Meyer (1963), Steinbach and Meyer (1965) and Kratochvíl and Zíková (1981) observed the elevation in the potassium concentration after parturition, whereas Senf $t$ and Rappen (1964) noticed variations in the concentration of this element which was confirmed also by us. Whereas in literature two times higher concentrations of $\mathrm{Ca}$ and $\mathrm{P}$ in colostrum compared to milk have been published (Gueguen 1961) we have not found such a marked differences between the level of colostrum from the 1st milking and from the 5th day. The phosphorus levels in colostrum from the first milking were found to be slightly lower than the values presented by the literature cited above. Individual variations, and thus the scatter of phosphorus values, were considerably smaller than in other macroelements.

The most marked seasonal differences were found in phosphorus where significantly higher level in winter season was observed in colostrum from the 3rd and 5th day after parturition. Steinbach and Meyer (1965) report higher sodium and potassium concentration in colostrum in winter season. This is in accordance with our findings, although this difference was found to be statistically significant in sodium and potassium on the 5th and 3rd day after parturition, resp.

Markedly higher values of titratable acidity, gamma globulins, proteins and GMT activity in colostrum with the total protein concentration of whey above $120 \mathrm{~g} / \mathrm{l}$, when compared with colostrum having insufficient total protein level, could be explained by the correlation of these parameters with total protein content of colostral serum. Particularly the relation of GMT to total protein and immunoglobulins 





is so close that GMT was identified by some authors as a secretion component of IgA. Only exacting separation methods enabled the separation of GMT from immunoglobulin fraction (Yasumoto 1976).

The interpretation of the results of biochemical analysis of colostrum and their confrontation with the findings published in literature has often been difficult. The reason is seen in great individual variability of colostrum components and extreme changes in dependence upon the time elapsed after parturition, proceeding in individual animals with great differences. When comparing the results the frequency of milking and the time period elapsed from parturition to sampling (at the first milking as well) have to be always taken into account. Particularly in the case of free housing when cows are brought into calving pen just before parturition, the composition of colostrum from the 1st milking can resemble that of milk due to selfsuckling.

The evaluation of colostrum quality is based in principle on the total protein level in whey from the 1st milking which should be higher than $120 \mathrm{~g} / \mathrm{l}$. This is made possible on the basis of highly positive correlation, found by us, between the concentration of total proteins and gamma globulins in colostral serum (Jagoš et al. in press). Indirect information about these parameters is also provided by the protein content, titratable acidity and GMT activity. As far as the colostrum digestion in calf abomasum is concerned, it is important to know the rennet coagulation time and the buffer capacity. The determination of the content of vitamin A, and possibly of vitamin $\mathrm{E}$ and minerals (particularly of $\mathrm{Ca}$ and $\mathrm{Mg}$ ) is also of importance. It also appears to be necessary to eliminate a possible occurrence of toxic compounds in colostrum. The importance of the determination of colostrum density has not been discussed here since a considerable attention to this parameter was paid by Fle en or and Stott (1980) and also by Rozkošný et al. (1981). Important information on colostrum quality could be obtained from a number of parameters; they, however, have to be assessed simultaneously to see their mutual connections and not individually.

The level of nutrition and the health condition of dairy cows as well as a probable development of the health condition of their calves in an early postnatal period could be assumed from the found values of individual parameters of colostrum and its quality.

\section{Sledování základních kvalitativních ukazatelů kolostra krav a jejich závislosti na ročním období a době po porodu}

V podmínkách velkokapacitního kravína pro 2144 dojnic bylo sledováno 19 fyzikálně chemických a biochemických ukazatelů kolostra krav a studován vliv ročního období a doby po porodu na tyto parametry. Od krav - kř́íženek českého strakatého plemene $\mathrm{s}$ černostrakatým nízinným byly odebírány průměrné vzorky kolostra z 1. nádoje, ze 3. a 5. dne po porodu. V letním období (červen) bylo vyŠetřeno kolostrum od $13 \mathrm{krav}$, v zimním období (únor) od $24 \mathrm{krav}$.

$\mathrm{U}$ většiny ukazatelů byly nejvyšši hodnoty zjištěny $\mathrm{v}$ kolostru z.1. nádoje a jejich nejvýraznější pokles jsme zaznamenali do 3 . dne po porodu. Pouze hodnoty $\mathrm{pH}$ a laktózy byly v kolostru z 1 . nádoje nejnižší. Obsah tuku, doba srážení kolostra syřidlem a koncentrace draslíku kolísaly bez zřetelné závislosti na době po porodu. V letním období byly alespoň ve dvou ze tří sledovaných nádojů zjištěny významně vyšší hodnoty vitamínu $A$, pufrační kapacity a sušiny, v zimním období významně vyšši hladiny fosforu. 


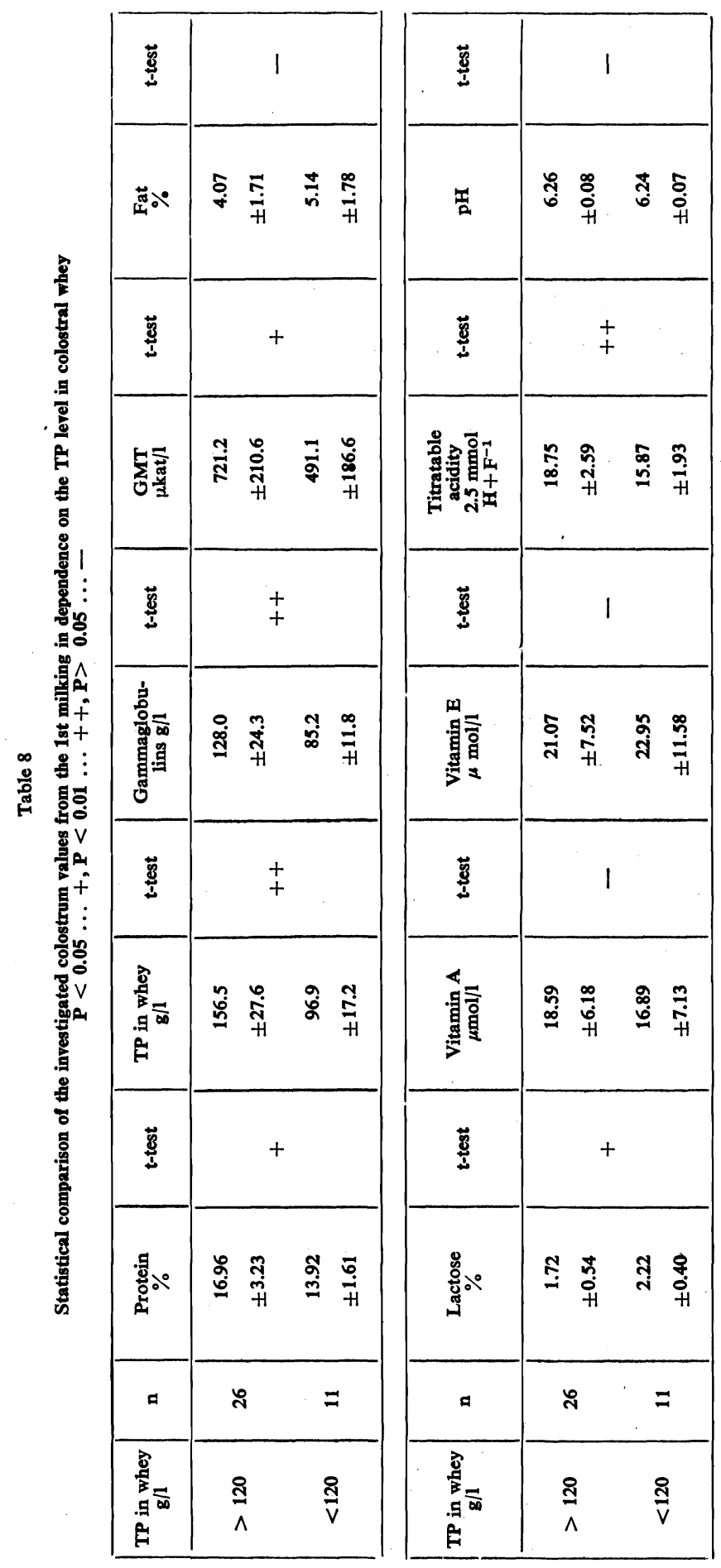




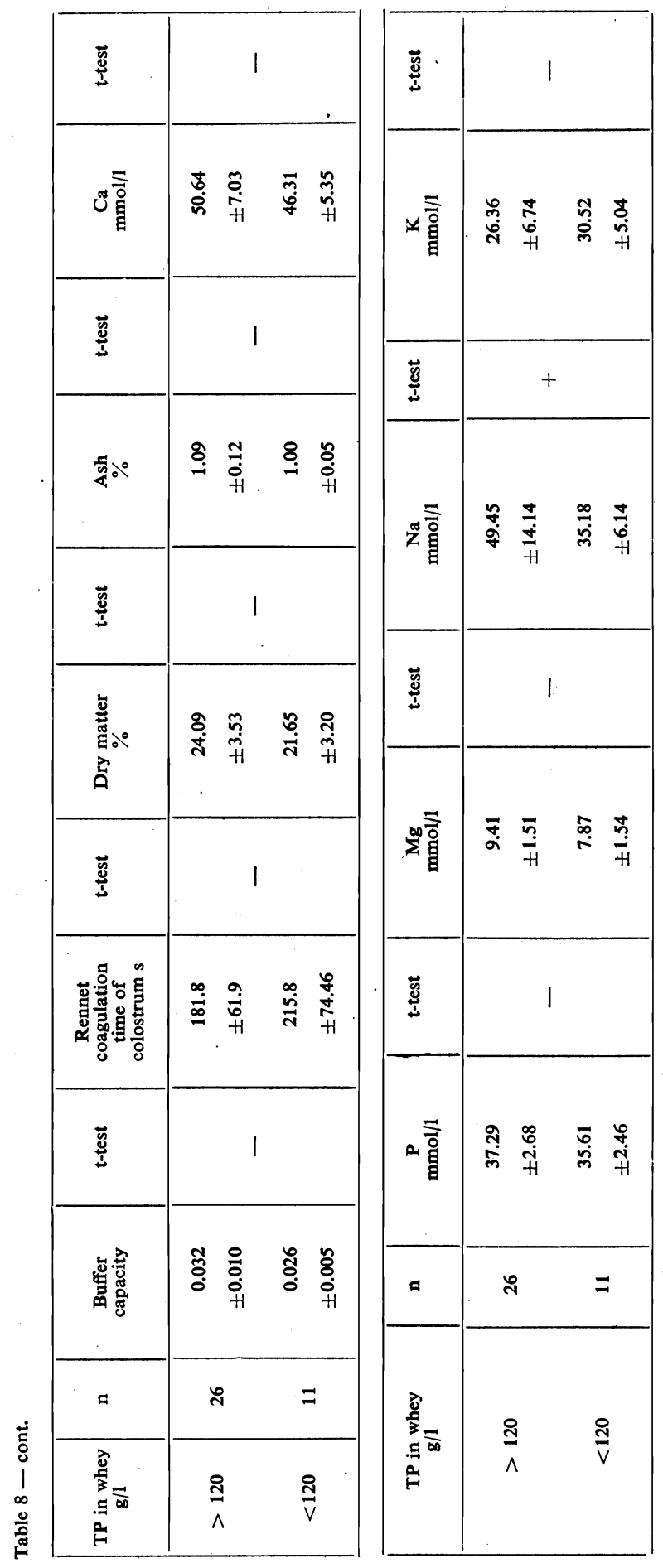


V kolostrální syrovátce byla prokázána přibližně 1000 krát vyšší aktivita GMT ve srovnání s krevní plazmou krav.

Ve vzorcích kolostra $\mathrm{z} 1$. nádoje s koncentrací celkové bílkoviny $(\mathrm{CB}) \mathrm{v}$ syrovátce nad $120 \mathrm{~g} / 1$ byla zjišš̌na vyšší titrační kyselost, vyšší hladina bílkovin, gama-globulinů, sodíku, aktivita GMT a nižší koncentrace laktózy oproti kolostru se sníženým obsahem CB v syrovátce.

Za rozhodující kritérium pro posouzení kvality kolostra lze považovat stanovení koncentrace CB v syrovátce kolostra $\mathrm{z} 1$. nádoje. Na základě stanovení kvality kolostra můžeme zpětně posoudit úroveň výživy, ošetřování i zdravotní stav matek v posledním trimestru gravidity i faktory, které budou ovlivňovat další vývoj jejich telat.

\section{Исследование основных качественных показателей молозива коров и их зависимости от времен года и периода после отела}

В условиях коровника для 2144 дойных коров проводились исследования 19 физико-химических и биохимических показателей молозива коров и влияния времен года и периода после отела на упомянутые параметры. У коров - помесей чешской пеструшки с черно-пестрым низменным племенем отбирали средние пробы молозива из первого надоя, третий и пятый день после отела. В летний период (июнь) были проведены исследования молозива 13 коров, в зимний период (февраль) -24 коров.

Самые высокие величины у большинства показателей были выявлены в полозиве от первого надоя и их самое существенное понижение отмечалось до 3 суток после отела. Только величины $\mathrm{pH}$ и лактозы были в молозиве первого надоя самые низкие. Содержание жиров и продолжительность свертывания молозива сычужиной, а также концентрация калия колебались без явной зависимости от периода отела. В летний период хотя бы двое из трех исследуемых надоев отличались существенно более высокими величинами витамина А, буферной емкостью и сухим остатком, в зимний период - существенно более высоким уровнем фocopopa.

В сыворотке молозива была установлена приблизительно в 1000 раз более высокая активность GMT по сравнению с кровяной плазмой коров.

В образцах молозива певото надоя с концентрацией общих белков (ОБ) в сыворотке более 120 г/л были установлены более высокая титруемая кислотность, более высокий уровень белков, гамма-глобулинов, натрия, активность GMT и более низкая концентрация лактозы по сравнению с молозивом с пониженным содержанием ОБ в сыворотке.

Решающим критерием определения качества молозива следует считать определение концентрации ОБ в молочной сыворотке молозива первого надоя. На основе определения качества молозива можно опятьтаки оценить уровень питания, уход и состояние здоровья коров в последнем триместре беременности и факторы, которые окажут влияние на дальнейшее развитие их телят.

\section{References}

ALIKAJEV, V. A. - PODKOPAJEV, V. M.: Lečenije novorožděnnych teljat, bolnych dispepsiej. Moskva 1966, 14 D. 
ALIKAJEV, V. A. - TUMANOVA, J. I.: Profilaktika i lečenije dispepsii teljat. Moskva 1977, $7 \mathrm{p}$.

BATRA, S. C. - DE MAN, J. M.: Beziehungen zwischen Labgerinnungszeit, Alkoholstabilität und Mineralbestandteilen der Milch. Milchwissenschaft, 19, 1964: 531-535.

BOUDA, J.: Význam biochemických ukazatelů pro diagnostiku onemocnění telat a studium metabolických vztahů mezi matkou a mládětem. Habilitation thesis, University of Veterinary Science, Brno, 1979, $137 \mathrm{p}$.

BOUDA, J. - DVOR̃́K, V. - MINKSOVÁ, E. - DVOŘÁK, R.: The activities of GOT, Gamma-GT, alkaline phosphatase in blood plasma of cows and their calves fed from buckets. Acta vet. Brno, 49, 1980: 193-198.

BOUDA, J. - JAGOS, P. - DVOŘÁK, V.: Fluorometrické určení vitamínů A, E v krevní plazmě, kolostru a v játrech skotu. Čs. Fysiol., 29, 1980: 351.

BOUDA, J. - JAGOŠ, P. - DVOŘAK, V. - HAMŠ́́K, V.: Vitamin A and carotene metabolism in cows and their calves fed from buckets. Acta vet. Brno, 49, 1980: 45-52.

BOUDA, J. - JAGOŠ, P. - DVOŘAK, R. - ONDROVÁ, J.: Vitamin E and C in the blood plasma of cows and their calves fed from buckets. Acta vet. Brno, 49, 1980: 53-58.

BOUDA, J. - JAGOŠ, P. - KLIMEŠ, J. - DVO ̌̌́Á, V.: Závislost hladin imunoglobulinů $\mathrm{v}$ krevním séru telat na době, množství a kvalitě vypitého mleziva. Veterinářství, in press.

COMBERG, G. - MEYER, H.: Der Mineralstoffgehalt zu Beginn der Laktation. Züchtungskunde, 35, 1963: 363-375.

ČSN 570530 Metody zkoušení mléka a tekutých mléčných výrobků. 1973.

DARDILLAT, J. - TRILLAT, G. - LARVOR, P.: Colostrum immunoglobulin concentration in cows: relationship with their calf mortality and with the colostrum quality of their female offspring. Annls Rech. vét., 9, 1978: 375-384.

ERICKSON, D. O. - HARROLD, R. L. - CARLSON, R. C.: Calf scours as it relates to selected nutritional components of colostrum. North Dakota Farm Research, 38, 1981: 18-20.

FLEENOR, W. A. - STOTT, G. H.: Hydrometer test for estimation of immunoglobulin concentration in bovine colostrum. J. Dairy Sci., 63, 1980: 973-977.

GAJDƯSEK, S.: Obsah mikroelementů v kravském mlezivu. Změny v obsahu mědi. In: Sborník provozně ekonomické fakulty Vysoké školy zemědělské v Českých Budějovicích, 76, 1965: $147-150$.

GAJDU゚SEK, S.: Studium bílkovin mléka. Ph. D. thesis, University of Agriculture, České Budějovice, $1969,149 \mathrm{p}$.

GARRET, O. F. - OVERMANN, O. R.: Mineral composition of colostral milk. J. Dairy Sci., 28, 1940: $13-17$.

GUEGUEN, L.: La composition minerale du lait et son adaptation aux besoin du jeune. Annls Nutr. Aliment., 25A, 1961: 335-381.

GUSHUL, V. A. - RYBINCEVA, A. A. - ALIKAJEV, V. A.: Sostav moloziva i někotoryje fiziko-chimičeskije svojstva soděržimogo syčuga u těljat. Sbornik naučnych trudov, Moskovskaja Ver. Akademija, 79, 1975: 82-84.

HAJDU, S. - BLAHO, R. -'HEČKO, R.: Štúdium humorálneho imunitného systému hovädzieho dobytka v postnatálnom období. II. čast. Imunoprofylaxia, Bratislava, 4, 1977: 45-64.

HOLM, G. E. - WEBB, B. H.: Buffer capacities of various milks and proprietary infant foods. Am. J. Dis. Child., 40, 1930: 260-268.

JAGOS, P. - BOUDA, J.: Protein metabolism in cows and their calves fed from buckets. Acta vet. Brno, 49, 1980: 59-66.

JAGOS, P. - BOUDA, J. - DVOŘ́́K, V. aj.: Studium aktivity enzymů, hladiny vitamínů a bílkovin $\mathrm{v}$ různých fázích ontogeneze $\mathrm{u}$ telat při metabolických poruchách. Project report, University of Veterinary Science, Brno, 1980, $65 \mathrm{p}$.

JAGOŠ, P. - BOUDA, J. - KLIMEŠ, J.: Studium biochemického složení kolostra krav a krve telat a stanovení referenčních biochemických a hematologických hodnot v krvi telat. Project report, University of Veterinary Science, Brno, 1983, 46 p.

JAGOS, P. - BOUDA, J. - KLIMES, J. - MUŽÍK, J.: Studium vybraných ukazatelů kvality mleziva v průběhu roku. Vet. Med., Praha, in press.

JANČǍ̆ÍIK, A.: Fyziologické aspekty výživy teĺata. In: SLANINA, L. aj.: Zdravie a chorobnost teliat v priemyselnej produkcii. 1. ed. Bratislava, Príroda 1977, pp 83-93.

JOHNSTON, W. S. - MACLACHLAN, G. K.: Digestive illness in the calf associated with non - coagulation of cow's milk. Vet. Rec., 101, 1977: 325-326.

JOHNSTON, W. S. - MACLACHLAN, G. K. - HOPKINS, G. F.: The association of non clotting of cow's milk with scour in the single suckled beef calf. Vet. Rec., 106, 1980: 174-175.

KADLEC, I.: Vliv zootechnických faktorů na kvalitu a složení mléka. Náš Chov, 11, 1982, addendum Mlékárenský prủmysl, pp 1-3.

KAVAK, CH.: Kislotnost moloka i vosproizvodstvo stada. Veterinarija, 1984, No 1: 50-51. 
KIRCHGESSNER, M.: Wechselbeziehungen zwischen Spurenelementen in Futtermitteln und tierischen Substanzen sowie Abhängigkeitsverhältnisse zwischen einzelnen Elementen bei der Retention. V. Die Wechselwirkungen zwischen verschiedenen Elementen in der Colostralund normalen Milch. Z. Tierernähr. Futtermittelk., 14, 1959: 270-277.

KOPECKÝ, J.: Kolísání složení mleziva červenostrakatého skotu vzhledem $\mathrm{k}$ různému časovému odstupu po otelení. Project report, University of Agriculture, Brno, 1967, 35 p.

KRATOCHVÍL, L. - ZADRAŽIL, K.: Některé nové poznatky o složení mleziva. In: Zborník na V. celoštátnu konferenciu Produkcia a zdravie teliat v priemyselných podmienkách chovu. Košice, 1981: 69-73.

KRATOCHVÍL, L. - ZÍKOVÁ, E.: Spektrum minerálních látek v mlezivu dojnic. Živočišná výroba, 26, 1981: 183-190.

KRUSE, V.: Yield of colostrum and immunoglobulin in cattle at the first milking after parturition. Anim. Prod., 12, 1970: 619-626.

KVAPILÍK, J. - SUCHÁNEK, B. - BRAUNER, J.: Přeměna mleziva na mléko zralé se zaměřením na jeho chemické a technologické vlastnosti. Živočišná Výroba, 20, 1975: 169-182.

LAMBRECHT, G. - FRERKING, H. - HENKEL, E.: Bestimmung von Ig G, Ig A und Ig M im Erstkolostrum des Rindes mit Hilfe der Nephelometrie und der radialen Immunodiffusion unter besonderer Berücksichtigung von Jahreszeit, Laktationsnummer und Vererbung. Dte tierärztl. Wschr., 89, 1982: 97-136.

LANE, H. L. - RICHTER, R. L. - RANDOLPH, H. E.: Influence of mastitis on properties of milk. VI. Buffer capacity. J. Dairy Sci., 53, 1970: $1381-1390$.

LEBEDA, M. - KUČERA, A. - BOUDA, J.: Vztah pufrovací kapacity krve a mléka krav v laktačním období. Vet. Med., Praha, 15, 1970: 621 -631.

LINDEN, G. - MARAVAL, B.: Colostrum de vache: composition minérale et activité de la phosphatase alcaline. Annls Biol. anim. Biochim. Biophys., 19/2A/, 1979: 337-341.

LOGAN, E. F.: The influence of husbandry on colostrum yield and immunoglobulin concentration in beef cows. Br. vet. J., 133, 1977: 120-125.

LOGAN, E. F.: Factors influencing the quantity and quality of colostrum in the cow. Vet. Sci. Commun., 2, 1978: 39-46.

MESSERLI, J. - FEY, M.: Messung des klassenspezifischen Antikörper - und Immunoglobulingehaltes in Colostrumseren von proteinimmunisierten Rindern. Zentbl. Vet. Med., 20, 1973: $177-198$.

MEYER, H. - STEINBACH, G.: Untersuchungen zur Bedeutung des Magnesiums für das neugeborene Kalb. Mh. Vet. Med., 25, 1970: 249-252.

MITJUSHIN, V. V.: Dispepsija novorožděnnych teljat. Moskva, Rosselchozizdat 1979, 111 p.

MOORE, T.: Vitamin A. Amsterdam, Elsevier 1957, 645 p.

NĚŽDANOV, A. G. - KUZNĚCOV, N. I.: Obměn věščstv u korov pri běreměnnosti, rodach i v poslerodovoj period. Veterinarija, 1978, No 4: 79-82.

NORCROSS, N. L.: Secretion and composition of colostrum and milk. J. Am. vet. med. Ass., 181, 1982: $1057-1060$.

REITER, B.: Review of nonspecific antimicrobial factors in colostrum. Annls Rech. vét., 9, 1978: $205-224$.

ROUX, R. - DAVICCO, M. J. - CARILLO, B. J. - BARLET, J. P.: Solanum glaucophyllum in pregnant cows. Effect on colostrum mineral composition and plasma calcium and phosphorus levels in dams and newborn calves. Annls Biol. anim. Biochim. Biophys., 19/1A/, 1979: 91 - 101 .

ROZKOŠNÝ, V. - BÁRTL, M. - FRANZ, J. aj.: Možnosti prevence neonatálních infekcí telat komplexními postupy. Project report, Veterinary Research Institute, Brno, 1981, 30 p.

SEIDEL, H. - SCHRÖTER, J. - LIEBETRAU, R. aj.: Verlaufsuntersuchungen zur Kalzium und Phosphorabgabe während der ersten 20 Laktationstage. Mh. Vet Med., 37, 1982: $612-616$

SENFT, B. - RAPPEN, W.: Untersuchung über die Zusammensetzung der Kolostralmilch bei schwarzbunten Kühen. Milchwissenschaft, 19, 1964: 577-583.

SCHMIDT, F. W. - KIM, J. W. - DERENBACH, J. - LANGHOLZ, H. J.: Kolostralimmunität und Aufzuchtleistung von Kälbern in der Mutterkuhhaltung. Tierärztl. Umschau, 37, 1982: $485-488$.

STEINBACH, G. - MEYER, H.: Untersuchungen zum Natrium-, Kalium-, Kalzium- und Magnesiumgehalt der Kolostralmilch unter besonderer Berücksichtigung seiner Beziehung zur Kälbersterblichkeit. Fortpfl. Haust., 1, 1965: 195-214.

STEINBACH, G. - MEYER, H.: Zur Bedeutung von Vitamin A und Karotin für das neugeborene Kalb. Arch. exp. Vet Med., 21, 1967: 35-41.

STEINBACH, G. - EIDNER, M. - MEYER, H.: Zur Auswirkung einer Vitamin -A-Zufütterung an tragende Muttertiere auf die Gesundheit der Kälber. Mh. Vet Med., 25, 1970: 191 - 195.

STOJIČEVIC, S.: Ispitivanje variranja procenta masti u kolostrumu krava u industriskom uzgoju. Vet. Glasn., 31, 1977: 145-153. 
SEBELA, F. - GAJDU゚ŠKK, S.: P̌̌́spěvek ke studiu závislostí mezi některými složkami mléka a jeho syřitelností. Acta univ. agric. (Brno), fac. agron., 17, 1969: 283 - 287.

SEBELA, F. - KLIĆNÍK, V.: Vlastnosti kravského meziva. - 1. sdělení. Chemické a biologické vlastnosti. Acta univ. agric. (Brno), fac. agron., 23, 1975: 517-525.

SEEBELA, F. - KLfČNÍK, V.: Kyselost mléka po nadojení ve vztahu k věku dojnice. Živočišná Výroba, 22, 1977: $161-170$.

TEPLÝ, M. aj.: Syłidla živočičná a mikrobiální. Praha, SNTL 1976. 288 p.

THOMPSON, J. L. - PAULI, J. V.: Colostral transfer of gamma glutamyl transpeptidase in calves. N. Z. vet. J, 29, 1981: 223-226.

YASUMOTO, K. - IWAMI, K. - FUSHIKI, T. - MITSUDA, H.: Bovine colostral $\gamma$-glutamyltransferase; its localization in skim milk membrane and irrelevance to secretory immunoglobulin A: FEBS Lett., 67, 1976: 328-330.

ZINOVJEVA, J. G.: Dinamika kalcija, magnija, fosfora $\mathrm{v}$ moloke korov v različnyje periody laktacii i stelnosti, Bjulleten V. N. I. I. fiziol. i bioch. selskochozjájstvennych životnych, Borovsk, 2, 1968: $43-47$.

ZUCKER, H. - KREUTZBERG, O. - HOLLWICH, W. - MATZKE, D. - KÖGEL, J. BURGSTALLER, G.: Untersuchungen zur Versorgung von Milchkühen mit B-Carotin .und Vitamin A. 2. Mitteilung: Einfluss auf Konzentration in der Milch sowie klinisch - gynäkologische und hormonalanalytische Befunde. Zentbl. Vet Med., A, 27, 1980: 525-533. 